\title{
Assessing the Carbon Consequences of Western Juniper (Juniperus occidentalis) Encroachment Across Oregon, USA
}

\author{
John L. Campbell, ${ }^{1}$ Robert E. Kennedy, ${ }^{2}$ Warren B. Cohen, ${ }^{3}$ and Richard F. Miller ${ }^{4}$ \\ Authors are ${ }^{1}$ Research Associate and ${ }^{2}$ Assistant Professor, Department of Forest Ecosystems and Society, Oregon State University, Corvallis, OR 97331, \\ USA; ${ }^{3}$ Professor, USDA Forest Service, Corvallis, OR 97331, USA; and ${ }^{4}$ Professor, Eastern Oregon Agricultural Research Center, Oregon State \\ University, Burns, OR 97720, USA.
}

\begin{abstract}
Our ability to assess the continental impacts of woody encroachment remains compromised by the paucity of studies quantifying regional encroachment rates. This knowledge gap is especially apparent when it comes to quantifying the impact of woody encroachment on large-scale carbon dynamics. In this study, we use a combination of aerial photography from 19851986 and 2005 and near-annual Landsat satellite imagery over the same period to assess the rates of encroachment by western juniper, Juniperus occidentalis Hook., into the grasslands and shrublands of eastern Oregon. The approximately 20-yr Landsat reflectance trajectories identified for the juniper woodlands of eastern Oregon did not correlate well with changes in juniper crown cover over the same period, suggesting that systematic trends in reflectance are being driven by vegetation other than juniper. Using a random sample of 150 aerial photography plots, we estimate the average aboveground accumulation of carbon in undisturbed juniper woodlands to be $2.9 \mathrm{~kg} \mathrm{C} \cdot \mathrm{m}^{-2} \cdot \mathrm{yr}^{-1}$; about $0.20 \mathrm{Tg} \mathrm{C} \cdot \mathrm{yr}^{-1}$ across all of Oregon. However, juniper removal by cutting and or burning, occurring at a rate of $<1 \% \mathrm{yr}^{-1}$, counteracted regional encroachment by about $35 \%$, bringing the net change in aboveground carbon down to $1.9 \mathrm{~kg} \mathrm{C} \cdot \mathrm{m}^{-2} \cdot \mathrm{yr}^{-1}$, about $0.13 \mathrm{TgC} \cdot \mathrm{yr}^{-1}$ across all of Oregon. This study illustrates the capacity of woody removal, over very small areas, to offset encroachment over very large areas and cautions against scaling site-level encroachment studies over entire regions.
\end{abstract}

\section{Resumen}

Nuestra habilidad para evaluar el impacto continental del incremento de las plantas arbustivas es limitada por la escasez de estudios cuantificando las tasas de invasión de plantas leñosas. La limitación de este conocimiento es especialmente aparente cuando se pretende cuantificar el impacto del aumento de las plantas arbustivas a gran escala de la dinámica del carbón. En este estudio, usamos una combinación de fotos aéreas que datan de 1985-1986 y 2005 así como imágenes anuales-cercanas Landsat satelitales del mismo periodo para evaluar las tasas de expansión de Western juniper Juniperus occidentalis Hook., en los pastizales y matorrales de este de Oregón. Los 20 años de las imágenes Landsat de trayectoria de reflectancia identificadas para los bosques de junípero del este de Oregón no correspondieron en buena medida con los cambios en la cubierta de la corona del junípero durante el mismo periodo de tiempo, indicando que las tendencia en la reflectancia están siendo impulsadas por un tipo de vegetación diferente al junípero. Usando una muestra aleatoria de 150 parcelas de fotografías aéreas, se estimó el promedio de acumulación de carbón en áreas de bosques de junípero sin perturbaciones, siendo $2.9 \mathrm{~kg} \mathrm{C} \cdot \mathrm{m}^{-2} \cdot \mathrm{yr}^{-1}$; cerca $0.20 \mathrm{Tg} \mathrm{C} \cdot \mathrm{yr}^{-1}$ a través de la región de Oregón. Sin embargo, la remoción de junípero mediante corte o quema, aconteciendo a una tasa de of $<$ $1 \% \mathrm{yr}^{-1}$, contrarrestó la expansión regional cerca del $35 \%$, reduciendo en el cambio neto en carbono sobre el suelo a $1.9 \mathrm{~kg} \mathrm{C} \cdot \mathrm{m}^{-2} \cdot \mathrm{yr}^{-1}$, cerca del $0.13 \mathrm{Tg} \mathrm{C} \cdot \mathrm{yr}^{-1}$ en la región de Oregón. Este estudio ilustra la capacidad de la remoción de plantas leñosas, sobre pequeñas áreas, para compensar la expansión sobre grandes áreas y advierte en contra de la ampliación de estudios de expansión área-nivel sobre regiones enteras.

Key Words: biomass, crown cover, Landsat, reflectance, remote sensing

\section{INTRODUCTION}

The expansion and infilling of woody species into grasslands or trees into shrublands, commonly referred to as woody encroachment, occurs in semiarid ecosystems throughout the

\footnotetext{
Research was funded in part by support from NASA Office of Earth Science, Ecosystems Program and the US Forest Service Forest Inventory and Analysis Program, in support of the North American Carbon Program (NACP) through their project titled "Role of North American Forest Disturbance and Regrowth in NACP: Integrated Analysis of Landsat and US Forest Service FIA Data-Phase 2."

Correspondence: John Campbell, Dept of Forest Ecosystems and Society, Oregon State University, Corvallis, OR 97331, USA. Email: john.campbell@oregonstate.edu

Manuscript received 12 January 2011; manuscript accepted 30 December 2011.
}

world (Archer 1994; Archer et al. 1995; van Auken 2000). Woody encroachment has long been a concern to resource managers because woody plants often expand at the expense of higher value livestock forage, and can represent a shift away from grassland and shrubland communities already made scarce or otherwise altered by agricultural activities. Localized studies aimed at understanding the causes and impacts of woody encroachment in North America have helped us understand how climate, land use, and fire can influence the interaction between woody plants and the nonwoody species with which they compete (see reviews by Archer et al. 1988, 1995; Scholes and Archer 1997). However, our ability to assess the continental impacts of woody encroachment remains compromised by the paucity of studies measuring large-scale 
regional encroachment rates (Asner et al. 2003; Strand et al. 2008). This knowledge gap is especially apparent when it comes to quantifying the impact of woody encroachment on large-scale carbon dynamics. Several recent assessments of terrestrial carbon pools across North America have identified woody encroachment as a potentially major, yet highly uncertain, component of the continental carbon budget (Houghton et al. 1999; Pacala et al. 2001; Houghton and Goodale 2004; CCSP 2007).

Because woody encroachment occurs primarily in precipitation zones marginal for forest establishment, the gross rates of aboveground carbon accumulation attributable to woody encroachment are small compared to forest production. However, unlike forest growth which is balanced by natural disturbance, timber harvest, and land conversion, woody encroachment is assumed to be largely one-directional with the potential result of a North American net carbon sink equivalent to that occurring across all forested lands (Houghton et al. 1999). The degree to which local estimates of encroachment rates apply across entire regions and the rates at which disturbances may actually be removing trees from formally encroached areas remain largely unquantified. Determination of these rates has been limited by a scarcity of historical inventories or imagery dating back far enough to detect this change.

An increasing presence of juniper in the North American Great Basin during the last century is well documented (Miller and Tausch 2002). Comparison of recent and historical photographs throughout the Intermountain West provide dramatic localized evidence of this encroachment, which is characterized by both expansion and infilling of open-growing juniper into an existing matrix of sagebrush-steppe (Miller et al. 2005). Although some palaeobotanical data suggest that this encroachment began with the end of the Little Ice Age in 1850 (Johnson and Miller 2006), rapid expansion of juniper appears to have coincided with Euro-American settlement during the late 1800s. The three factors most often implicated in the current juniper encroachment are reduced competition by grasses facilitated by livestock grazing (Miller and Rose 1995), reduced fire mortality resulting from lower amounts of surface fuels and active fire suppression (Savage and Swetnam 1990; Miller et al. 2005; Swetnam et al. 2010), and reproductive momentum initiated by favorable climate conditions in the late 1800s (Soule et al. 2004). Since juniper began its encroachment $110-160 \mathrm{yr}$ ago, the total land area occupied by juniper throughout its range is believed to have increased by about 10 times (Miller and Rose 1999), with densities up to 250 trees $\cdot \mathrm{ha}^{-1}$ in areas originally sustaining less than 10 trees $\cdot \mathrm{ha}^{-1}$. Gedney et al. (1999) compared a juniper inventory conducted in 1936 (Cowlin et al. 1942) to a similar one conducted in 1988 (Gedeny et al. 1989) and concluded the land area in Oregon having at least 5\% juniper crown cover increased from 170000 ha to 890000 ha over this 52 -yr period. Clearly, juniper expansion is affecting large land areas, yet the rate at which regional carbon stocks are changing as a result remains unquantified.

In this study, we use a combination of aerial photography from 1985-1986 and 2005 and near-annual Landsat satellite imagery over the same period to assess the rates of encroachment by western juniper (Juniperus occidentalis Hook. var. occidentalis, hereafter referred to as juniper) into the grasslands and shrublands across eastern Oregon. Our specific objectives were to 1) quantify the range and variability of encroachment rates and associated changes in aboveground carbon storage throughout the semiarid regions of Oregon, 2) assess the rates at which juniper is being removed from the region due to natural and human disturbances, and 3) explore the utility of 20 sequential years of Landsat imagery for detecting slow but long-term changes in juniper cover.

\section{METHODS}

\section{Remote Sensing of Woody Encroachment}

Prior efforts to quantify juniper encroachment with Landsat imagery have met with mixed results. Using Landsat imagery from 1985 and 2005, Sankey and Germino (2008) successfully employed a spectral unmixing technique to map changes in the presence or absence of juniper across an area in southern Idaho, and Bradley (2008) derived a measure of fractional greenness from Landsat images taken in 1985, 1995, and 2005 to map relative changes in juniper cover across an area in central Nevada. Both of these studies achieved a precision of change detection adequate for mapping spatial patterns of juniper encroachment and successfully correlated these patterns with other biophysical parameters. To date, however, the only approaches to mapping juniper encroachment with accuracy necessary to determine changes in biomass have relied on various forms of aerial photography (Weisberg et al. 2007; Strand et al. 2008; Davies et al. 2010). Because of the opengrown nature of juniper throughout most of its range, individual tree crowns are readily discernable in moderate- to high-resolution aerial photography (i.e., $\leq 1 \mathrm{~m}$ ). This situation lends itself well to various forms of automated cover assessment based on individual crown detection (see Hill and Leckie 1999; Bai et al. 2005) or binary texture analysis (Strand et al. 2008). When such photographic imagery is available for two points in time, quantitative assessment of encroachment can be quite accurate, but only over relatively small areas (e.g., $<1000 \mathrm{~km}^{2}$ ).

The use of nearly annual change detection over $20 \mathrm{yr}$ employed in this study was meant to improve the signal-tonoise ratio over previous attempts to map change in juniper cover. Moreover, by building models that relate change in reflectance directly to change in juniper cover, rather than models that relate reflectance to absolute cover at multiple points in time, we reduce the sources of modeling error from two to one, theoretically reducing prediction error.

\section{Study Area}

Juniper woodlands exist throughout eastern Oregon, cooccurring with sagebrush (Artemisia spp.) steppe. For this study, we considered the area within four $19000-\mathrm{km}^{2}$ Thiessen polygons representing the nonoverlapping interior portions of Landsat scenes (path-row) 45-29, 45-30, 43-29, and 43-30 (Fig. 1). We selected these four areas because together they encompass nearly half of the juniper woodlands in Oregon and include all six of the ecological provinces in which juniper woodlands are a significant component, namely the Eastern Cascades, Blue Mountains, Columbia Plateau, Northern Basin Range, Central Basin Range, and Snake River Plain (Omernik 1987). Aerial photo analysis (from which all quantitative 


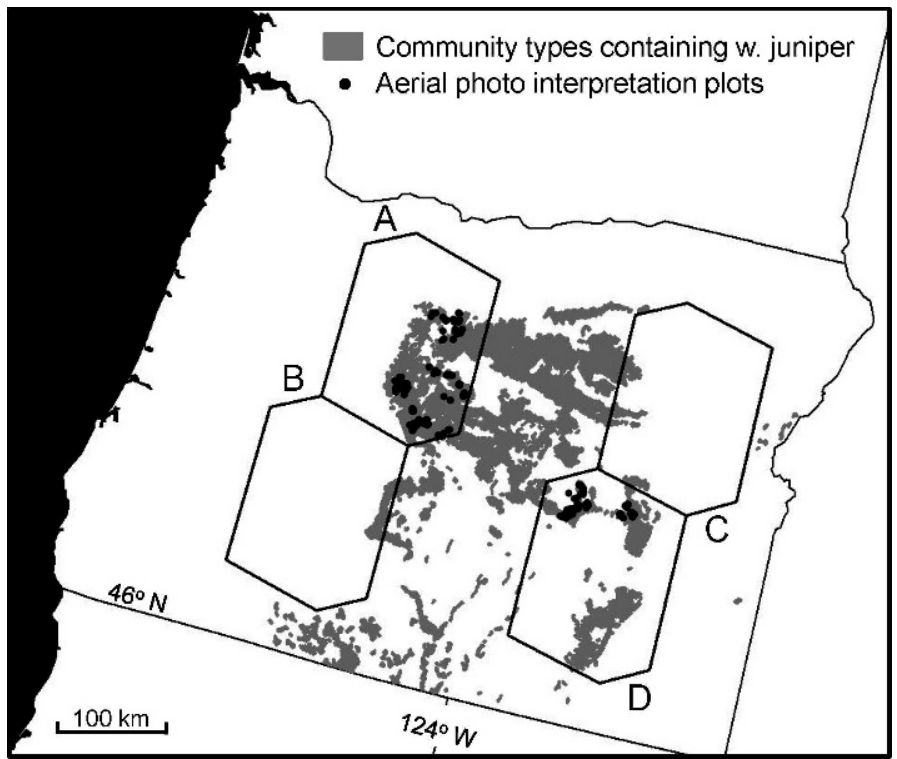

Figure 1. Location of the photo interpretation points and Landsat scenes assessed in this study relative to the distribution of juniper woodlands in Oregon. Thiessen polygons $\mathbf{A}$ through $\mathbf{D}$ represent the nonoverlapping interior portions of Landsat scenes (path-row) 45-29, 45-30, 43-29, and 43-30, respectively.

estimates of juniper cover change were derived) was limited by photo availability to areas classified by the Oregon gap analysis program (GAP) vegetation map (Kagen and Caicco 1992) as potentially containing juniper. Landsat change detection, for which we had full coverage, was performed across all areas classified by the Oregon GAP vegetation map as either juniper woodlands or sage steppe.

\section{Sampling of Aerial Photography}

A comparison of juniper crown cover in aerial photographs taken in 2005 with those taken in either 1985 or 1986 (hereafter referred to as the 20-yr measurement interval) served both as a means of directly assessing regional rates of juniper encroachment and the basis for interpreting change detection in the Landsat imagery collected over this 20-yr interval.

Our sample unit for aerial photo interpretation was a 1-ha circular plot. For this study we employed two different sampling schemes. The first sampling scheme, designed to assess the full range and variability of juniper encroachment throughout the study area, involved random plot placement requiring only that each fell within areas classified as western juniper woodlands according the Oregon GAP vegetation map (Kagen and Caicco 1992) and contained at least some visible juniper. A lack of quality aerial photos excluded about $15 \%$ of the juniper woodlands in our study area from consideration. Still, random selection of available photos provided good dispersion (see Fig. 1). A total of 92 such plots were measured, including several that exhibited declines in juniper cover resulting from natural and anthropogenic disturbance. The second sampling scheme, designed to confirm observed spectral change in the Landsat imagery, was deliberately stratified across the range of change values in our Landsat-based change map (see description below). In this sampling scheme, we started with random points and selected the nearest location exhibiting select values from our change detection map, classified as Western Juniper Woodlands vegetation type, containing at least some juniper crown cover, and not showing any signs of disturbance in the 2005 aerial photo. A total of 108 such plots were considered, 58 of which were rejected due to visible signs of disturbance such as fire, felling, agricultural expansion, or road building.

\section{Interpreting Aerial Photography}

To insure the highest possible accuracy over a wide range of photographic conditions, we quantified juniper cover by manually tracing individual crowns visible in the aerial photos. Paper photos from the 1980s were first digitized, then uploaded into ArcMap and rectified to $0.5-\mathrm{m}$ accuracy with the 2005 digital photos using, as reference points, at least four trees recognizable in both photos. Once photos were coregistered, crown area was assessed independently in each photo date, not in reference to each other. As shown in Figure 2, crown area in each 1-ha plot was determined by tracing an isosceles triangle over each juniper, with the base spanning crown diameter perpendicular to sun angle and a height spanning crown radius in the direction of the sun. The use of such triangles and Menelaus' theorem allowed us to approximate individual crown area to the nearest ellipse by marking only three points unobscured by shadow, where crown area $=$ area of traced triangle multiplied by 3.14 .

The resolution of the photos afforded point placement precision of approximately $0.5 \mathrm{~m}$. Presuming measurement error is both random and normally distributed, this $0.5-\mathrm{m}$ precision translates into a plot-level crown cover measurement error ranging from $4 \%$ (for 1-ha plots containing more than 20 crowns averaging $9 \mathrm{~m}$ in diameter) to $10 \%$ (for 1-ha plots containing less than 20 crowns averaging $3 \mathrm{~m}$ in diameter). Juniper crowns smaller than $1 \mathrm{~m}$ in diameter were not reliably detectable in these photos and were excluded from measurement even when their presence was suspected. In some cases, multiple small crowns (detected in the 1985 imagery) had, by 2005 , coalesced into a single larger crown.

\section{Allometry}

Juniper crown cover, as observed in the aerial photography was converted to aboveground biomass for each individual tree using the following equation:

$$
\begin{aligned}
& \text { Total aboveground biomass }(\mathrm{kg}) \\
& \qquad=e^{2.07+\left(1.09 \times \ln \left[\operatorname{projected} \text { crown area }\left\{\mathrm{m}^{2}\right\}\right]\right)}
\end{aligned}
$$

This relationship $\left(R^{2}=0.83\right)$ was derived by Sabin (2008) from the harvest of 97 western juniper trees ranging in size from $11 \mathrm{~cm}$ to $63 \mathrm{~cm}$ basal diameter at three widely dispersed locations in eastern Oregon and northeastern California. Total aboveground biomass was converted to carbon mass by using a factor of $0.5 \mathrm{~g} \mathrm{C}$ per gram biomass.

\section{Landsat-Based Change Detection}

We developed maps of possible juniper encroachment using outputs from LandTrendr algorithms and analysis, which are described in detail in Kennedy et al. (2010) and Kennedy et al. 

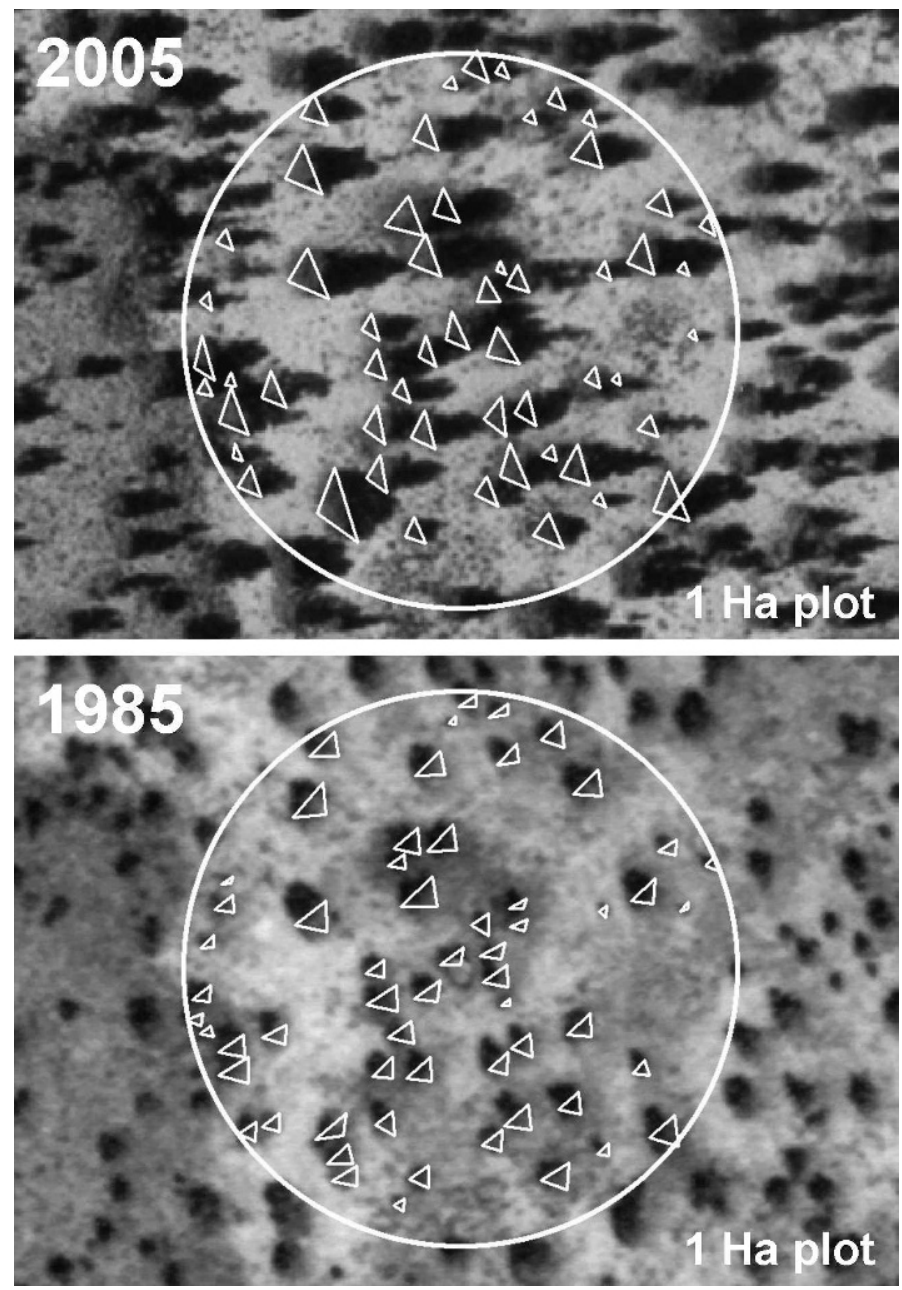

Figure 2. Photo interpretation of juniper cover. After rectifying the paired images from 1985 (or 1986) and 2005, an isosceles triangle was manually traced over each juniper tree contained in the 1-ha circular plot, with the base spanning crown diameter perpendicular to sun angle and a height spanning crown radius in the direction of the sun. The area of each triangle was calculated automatically using ArcMap software (ESRI, Redlands, CA) and converted to projected elliptical crown area as triangle area $\times \pi$.

(in press). Briefly, a time series of georectified annual Landsat TM/ETM+ images from 1984 to 2007 was acquired from the US Geological Survey Landsat archive $^{1}$ for the four path-rows shown in Figure 1. With more than 100 individual images used, dates of individual images are not shown, but images were targeted in each year that were close to 15 August, as vegetation was consistently senesced by this date, maximizing contract. A single image in each time series was corrected to approximate surface reflectance using the COST approach (Chavez 1996), and all other images were then normalized to that image using the MADCAL relative radiometric normalization of Canty et al. (2004). Tasseled-cap brightness, greenness, and wetness were calculated using reflectance factor coefficients (Crist 1985). After preparing image time series, the LandTrendr temporal segmentation algorithms were applied on a pixel basis. Temporal segmentation uses goodness-of-fit statistics to identify the periods of consistent trends and abrupt

'glovis.usgs.gov

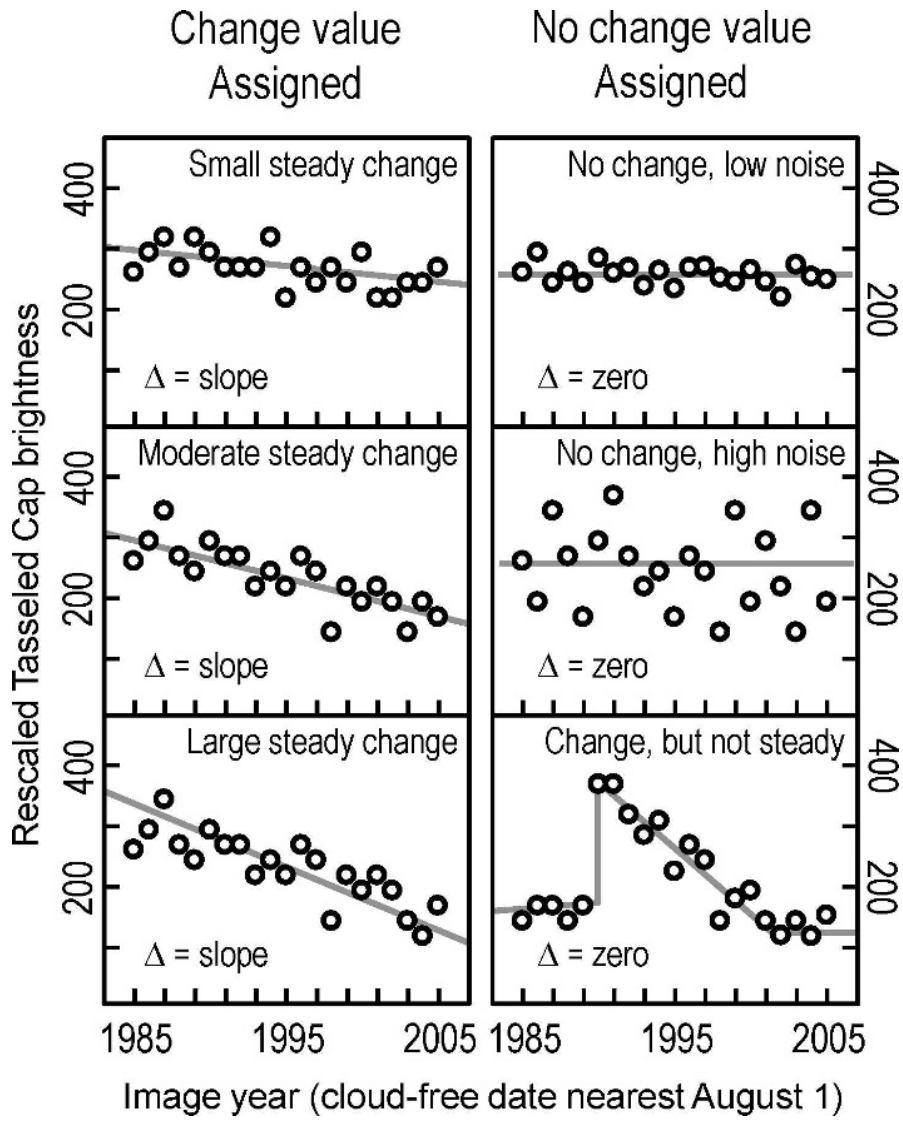

Figure 3. Examples of how LandTrendr was used to identify and quantify steady negative trends of $18 \mathrm{yr}$ or more in brightness for each Landsat pixel. As shown on the right, pixels were assigned a default change value of zero when reflectance values over this period were flat, too noisy, or showed signs of punctuated change. Because we were attempting to detect juniper cover increases, any pixels exhibiting positive trajectories in brightness were also assigned a default change value of zero (not shown). As shown on the left, when brightness decreases over at least $18 \mathrm{yr}$ are fit with a single negative linear segment, change was assigned according to the magnitude of the decrease.

changes in a time series, simplifying the often noisy yearly data into simplified segments bounded by vertices that identify directional change. Insofar as spectral trends are caused by changes in the surface condition, these segments correspond to time periods when consistent processes, such as encroachment, could be occurring.

For the purposes of this study we were most interested in identifying locations where long, uninterrupted changes in reflectance were occurring, particularly diminishment in surface brightness that might be caused by increased shadowing of growing juniper crowns. Figure 3 illustrates how LandTrendr classified each pixel into one of two categories. The first category includes pixels exhibiting an uninterrupted decrease in tasseled-cap brightness for at least $18 \mathrm{yr}$. A change magnitude was assigned to each pixel in this first category according to the best linear fit over this period. The second category includes pixels exhibiting either an increase in brightness or no quantifiable decrease in brightness, due to high noise, low signal, or punctuated changes. All pixels in this second category were assigned a default change magnitude of zero. Such analysis was also performed for the other two primary axes 
$\Delta$ Juniper cover $\left(\mathrm{m}^{2}\right.$ cover $.100 \mathrm{~m}^{-2}$ ground. year $\left.^{-1}\right)$

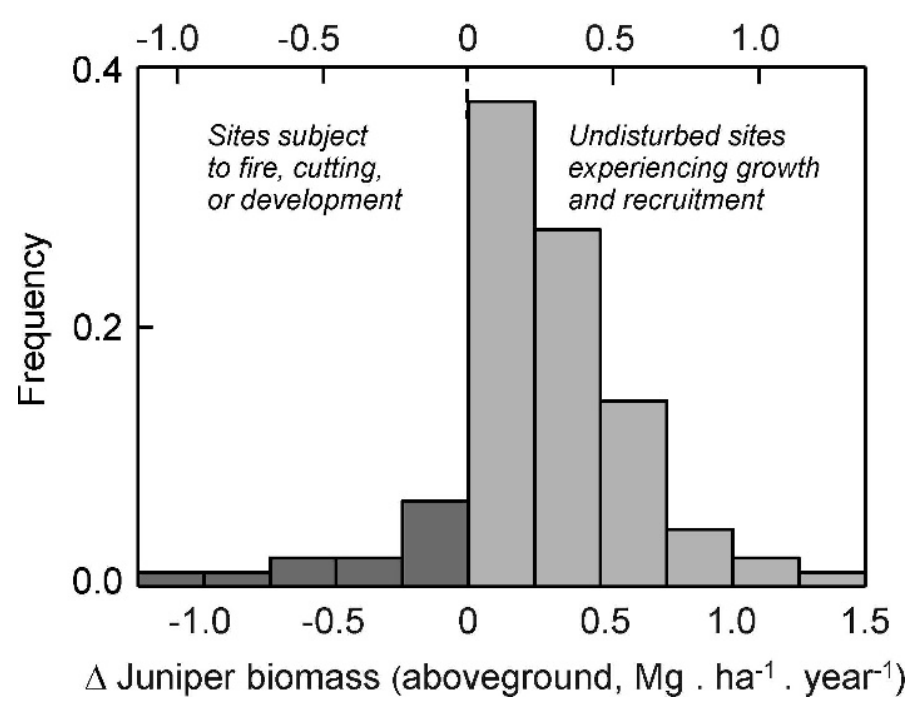

Figure 4. Frequency distribution of juniper encroachment and loss over a 20 -yr period, as determined through photo interpretation. The smooth shape of this distribution endorses the adequacy of our sample size. It is clear from this graph that regional juniper encroachment must be assessed as the dynamic sum of small gains over broad areas and large losses over much smaller areas.

of tasseled-cap space (i.e., greenness and wetness), though initial results did not warrant further analysis of these indices.

When comparing the change detected in Landsat imagery to the change in juniper cover observed in the aerial photography, we used the average detected change among the 9 to 12 Landsat pixels whose majority was contained in the 1-ha circular photographic plot.

\section{RESULTS}

\section{Aerial Photo Interpretation}

Of the 92 randomly selected sample plots, 62 showed increases in juniper crown cover due to growth and infilling and 30 showed decreases in juniper crown cover due to felling and fire over $20 \mathrm{yr}$ prior to 2005 . The changes in juniper cover and aboveground biomass over the 20 -yr measurement interval exhibited both positive and negative changes, tending toward small increases (Fig. 4). Among the undisturbed plots, the absolute increase in juniper cover averaged $32 \pm 3$ $\mathrm{SE} \mathrm{m}^{2} \cdot \mathrm{ha}^{-1} \cdot \mathrm{yr}^{-1}$ (range $\left.=0-135\right)$ which translates to an increase of $184 \mathrm{~kg} \cdot \mathrm{ha}^{-1} \cdot \mathrm{yr}^{-1}$ of aboveground juniper carbon (range $=0-715, \quad \mathrm{SE}=17$ ). Among the disturbed plots, losses of juniper cover averaged $62 \mathrm{~m}^{2} \cdot \mathrm{ha}^{-1} \cdot \mathrm{yr}^{-1}$ of juniper cover (range $=0-145, \mathrm{SE}=10$ ), which translates to a loss of $340 \mathrm{~kg} \cdot \mathrm{ha}^{-1} \cdot \mathrm{yr}^{-1}$ of aboveground juniper carbon (range $=0-817, \mathrm{SE}=56$ ), though it is reasonable to assume that these losses were incurred during single disturbance events occurring some time during the 20-yr measurement interval. On balance (including plots where juniper cover was lost), our regional sample exhibited an increase in juniper crown cover and biomass of approximately $23 \%$ of initial values over the$20 \mathrm{yr}$ measurement interval (approximately 1\% annually). As

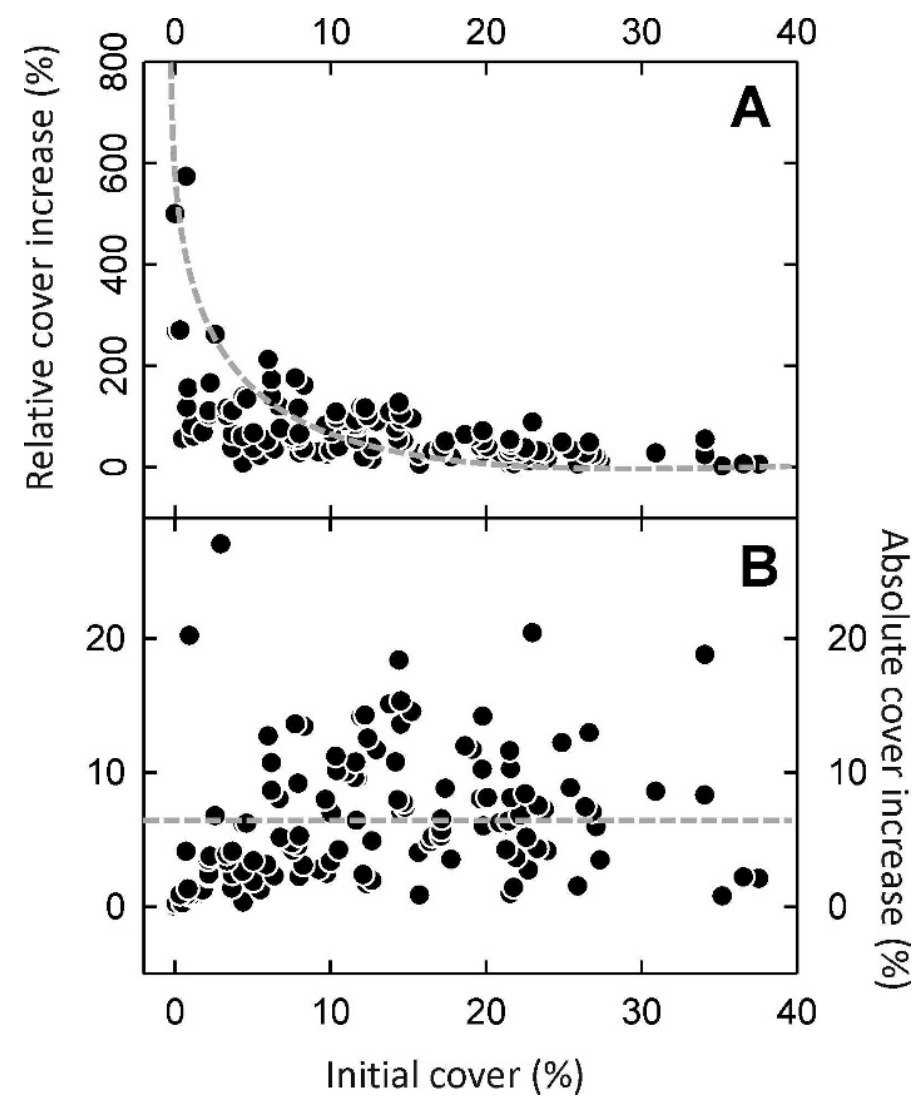

Figure 5. Relative and absolute increases in juniper crown cover over a 20-yr period. A, A steep negative relationship between initial cover (in 1985) and relative growth reveal that individual trees are growing and/or infilling at slower rates in high-cover stands than in low-cover stands. B, However, the balance between higher individual growth rates in lower-cover sites and lower individual growth rates in higher-cover sites is such that absolute increases in juniper cover are largely independent of initial cover. The regression line fit in $\mathrm{A}$ is $y=407 e^{-0.20 \mathrm{x}}\left(R^{2}=0.20\right)$; the regression line fit in $\mathrm{B}$ is a flat line where $y=5.36\left(R^{2}=0.03\right.$, slope not significantly different than zero).

shown in Figure 5A, plots with low initial juniper cover exhibited greater proportional increases than did those with higher juniper cover. However, the product of high growth rates in low-cover sites was similar to that of low growth rates in high-cover sites. As such, absolute increases in juniper cover varied independently of initial amount of juniper present (Fig. 5B).

\section{Change Detection in Landsat Imagery}

According to LandTrendr methodology, Landsat pixels tagged as exhibiting steady, uninterrupted change are those in which the annual chronology of reflectance can be fit within specified statistical limits, to a single linear trajectory. As shown in Figure 6 , approximately $27 \%$ of the total study area and $26 \%$ of the area inhabited by juniper exhibited a steady, uninterrupted decrease in tasseled-cap brightness for at least $18 \mathrm{yr}$ between 1984 and 2007, indicating an increase in woody plant cover. These proportions were substantially more than that observed for either tasseled-cap greenness or wetness, indicating that tasseled-cap brightness is the index most sensitive to the steady decadal changes in vegetation occurring in these juniper woodlands. 


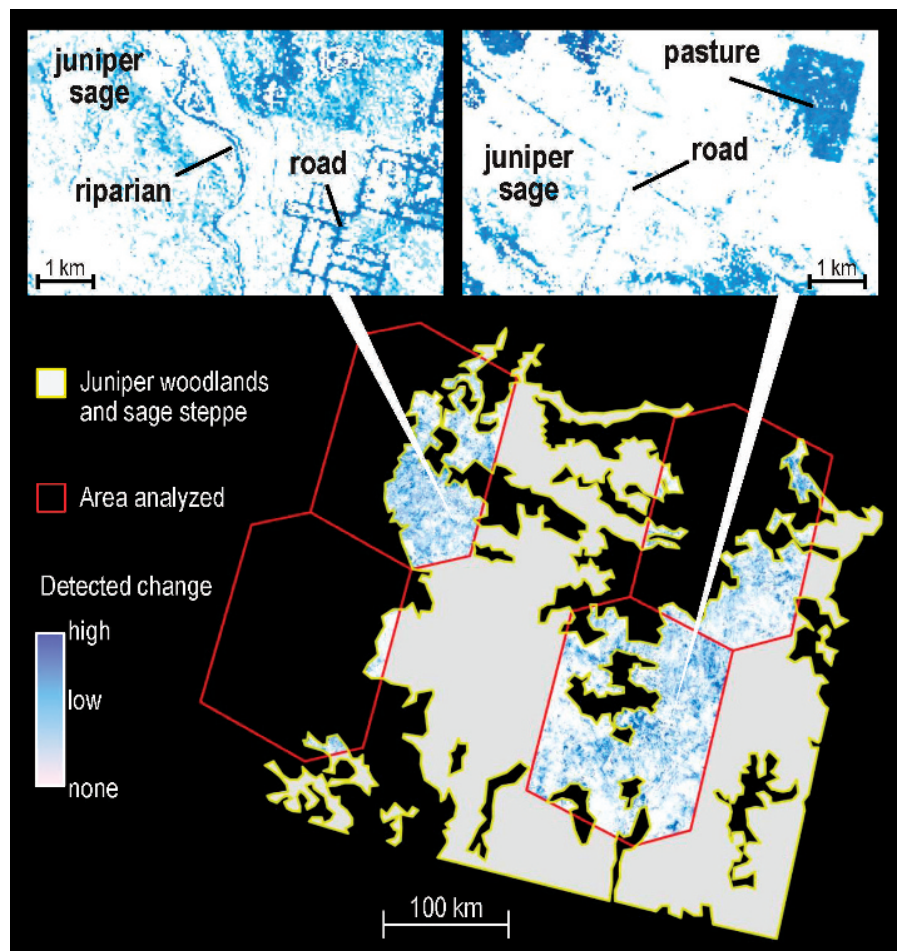

Figure 6. The detection of steady vegetation change for juniper woodlands of Oregon. Blue areas are those that exhibited steady, uninterrupted decreases in tasseled-cap brightness for at least 18 continuous years sometime between 1984 and 2007. White areas within analyzed polygons are those that exhibited no steady, uninterrupted decreases in tasseled-cap brightness. Overall, $27 \%$ of the area analyzed exhibited some steady decline in brightness over the measurement period. These locations were often identifiable as landform, vegetation, and anthropogenic features.

The spatial patterns of change detection followed some landforms, such as hill slopes and riparian corridors, and some anthropogenic features, such as roadways and agricultural activity (Fig. 6). However, as shown in Figure 7, there was no compelling relationship between these steady brightness changes and the increases in juniper cover observed in the photo plots, nor did juniper crown cover in 2005 (as observed in the photo plots) correlate well with tasseled-cap brightness in 2005 .

\section{DISCUSSION}

\section{Change Detection in Landsat Imagery}

By using $>20$ individual years of Landsat imagery, we were able to identify and quantify subtle change trajectories despite what was often high levels of interannual noise. However, these steady changes in surface reflectance did not correlate well with changes in juniper crown cover over the same period.

Several studies have shown a strong negative correlation between both tasseled-cap brightness and greenness and the proportion of conifer cover, relative to low-stature shrubs (Cohen and Spies 1992; Cohen et al. 2001; Song et al. 2007; Healey et al. 2008). These basic relationships form the foundation for mapping long-term change trajectories such as

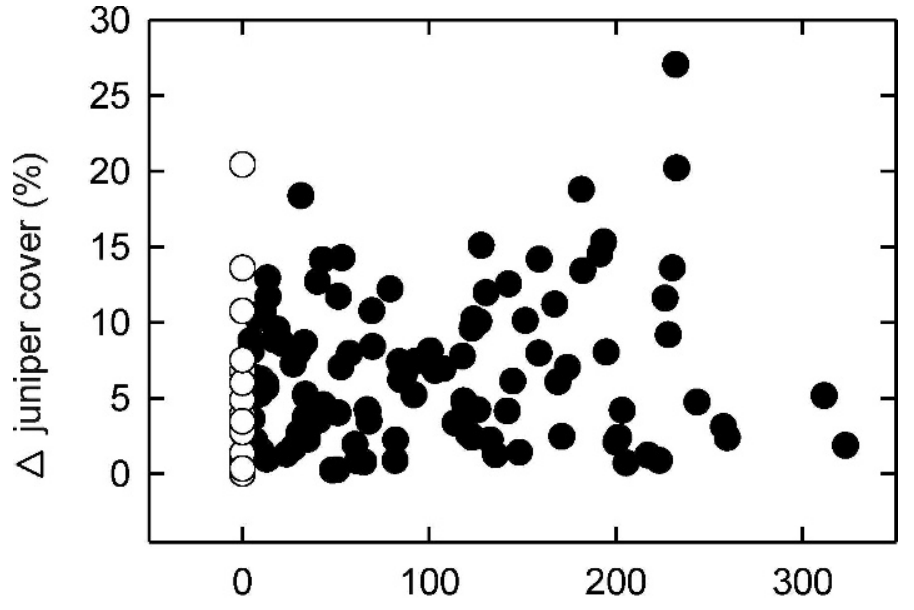

$\triangle$ Rescaled Tasseled Cap Brightness

Figure 7. Relationship between the steady change over a 20-yr period detected in Landsat imagery by LandTrendr and the change in juniper cover assessed at the plot level through photo interpretation. White circles are those that were assigned a change value of zero due to that plot exhibiting either no detectable change or interrupted change in the Landsat imagery.

conifer growth following fire and harvest (Cohen et al. 2010; Kennedy et al. 2010) and, to a lesser degree, the slow spread of insect-caused tree mortality (Kennedy et al. 2010). For these reasons, we had expected that increasing juniper cover, in a matrix of grass and low-stature shrubs, would be the primary driver of long-term decreases in brightness. Instead, it appears that our detected changes are being driven by slow, steady changes in other surface features, most likely the soil and nontree vegetation, which make up between $80 \%$ and $90 \%$ of the reflectance signature. One can assume that juniper crowns have similar reflectance throughout eastern Oregon, but the soil and nontree vegetation that juniper expansion affects is variable as is its response to juniper presence and growth (Miller et al. 2005). The fact that we can detect widespread low-magnitude changes in vegetation in so many locations is very promising, but more work will be necessary to interpret this rich pattern. At least some of the steady uninterrupted change identified in this study appears to be initiated by anthropogenic activity such as road construction and agricultural conversion (see Fig. 6). It is notable that although some roads show up well in our change detection map, most do not at all.

\section{Gross Regional Encroachment Rates}

The gross rate at which juniper is encroaching across our study, that is, the increase in juniper cover among our randomly placed photo plots showing no sign of juniper loss (average 32, median $30 \mathrm{~m}^{2}$ juniper crown $\cdot \mathrm{ha}^{-1} \cdot \mathrm{yr}^{-1}$ ) was within the range reported by other studies. At a single location in eastern Oregon, Knapp and Soule (1998) reported rates of $55 \mathrm{~m}^{2}$ juniper crown $\cdot \mathrm{yr}^{-1}$. Working in multiple sites in eastern Oregon and northern California, Miller and Rose (1995) reported rates of $5-20 \mathrm{~m}^{2}$ juniper crown $\cdot \mathrm{yr}^{-1}$ depending on tree density. In southern Idaho, Sankey and Germino (2008) reported rates of $9 \mathrm{~m}^{2}$ juniper crown $\cdot \mathrm{yr}^{-1}$ and, over a 4000 $\mathrm{km}^{2}$ area in southern Idaho, Sankey and Germino (2008) found 


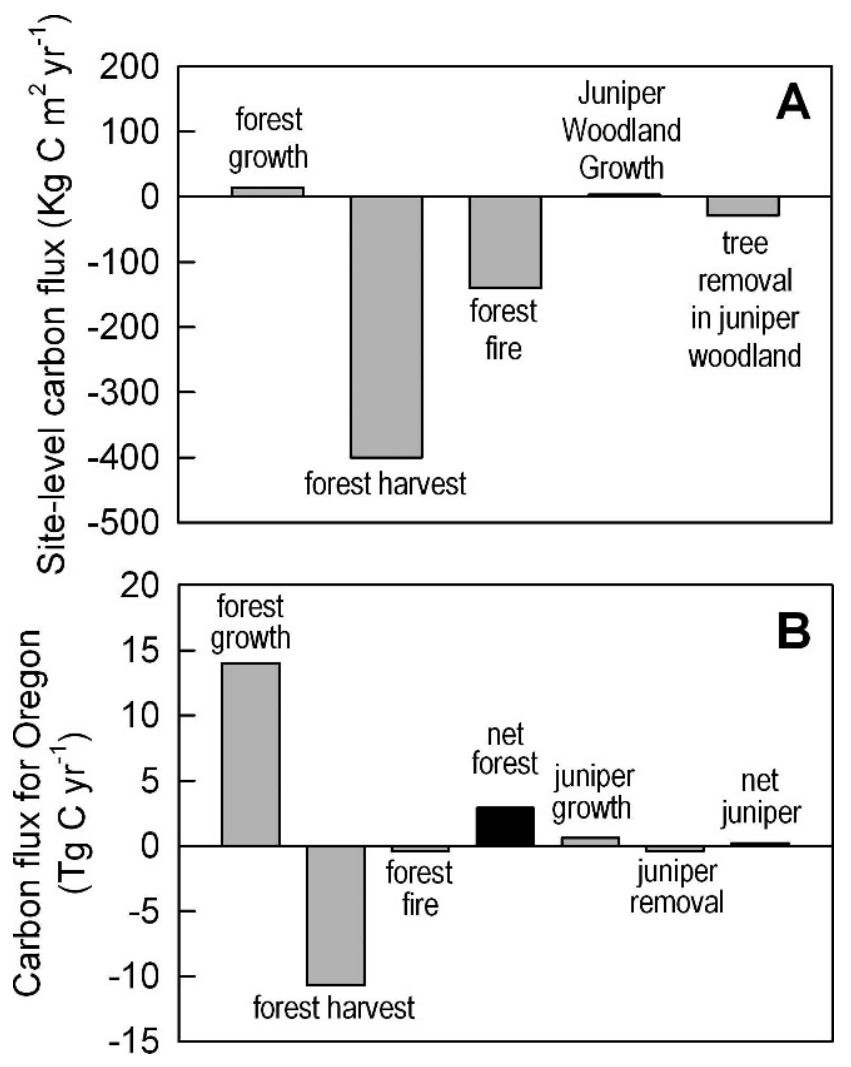

Figure 8. Changes in aboveground carbon stocks attributed to juniper encroachment compared with simulated ecosystem fluxes, A, per unit area and $\mathbf{B}$, across all of Oregon. Net carbon accumulation in juniper woodlands, like forest biomass, is the small balance between large losses over small areas and small gains over larger areas. Note also that the gross and net carbon fluxes attributed to juniper encroachment in Oregon is very small compared to that of forests. Juniper fluxes are from this study, other fluxes are adapted from Turner et al. (2007).

rates of $10 \mathrm{~m}^{2}$ juniper crown $\cdot \mathrm{yr}^{-1}$. It is worth appreciating that with the exception of Strand et al. (2008), these earlier studies were designed primarily to describe local spatialtemporal patterns of encroachment and not regional rates. As such, they may have been biased toward locations where encroachment was most reliably occurring. This is a point worth considering whenever extrapolating local encroachment studies to regional scales.

Notably, the rate of juniper increase did not appear to slow at higher levels of cover, suggesting that juniper cover across eastern Oregon is not approaching its carrying capacity (as described for woody encroachment by Knapp et al. 2008). This observation is consistent with dendrochronological studies showing that juniper in eastern Oregon often grow at steady rates even at relatively high densities (20-30\% cover). Certainly, not all of the juniper woodlands in eastern Oregon are relentlessly marching toward $40 \%$ crown cover (most undisturbed sites are experiencing less than $0.1 \%$ juniper expansion annually), but the exact carrying capacity of juniper in Oregon remains an open question.

\section{Net Regional Encroachment Rates}

What sets this study apart from most woody encroachment research is that it provides a sense for how encroachment rates in undisturbed areas are balanced by tree loss in disturbed areas. Although the frequency of juniper disturbance is relatively small, disturbances often resulted in the complete removal of the aboveground juniper biomass. As such, standlevel disturbance occurring at a landscape-wide frequency of $<1 \%$ annually counteracted encroachment in undisturbed locations by $35 \%$.

The most common agent of juniper mortality observed in this study was fire. Though we could not distinguish between prescribed fire and wildfire, many burned plots showed signs of juniper felling, indicating that the site was subject to a deliberate juniper control prescription. The next most common agent of juniper mortality was development, particularly residential and agricultural building and associated road construction. The consideration of tree removal in assessing the impacts of woody encroachment is essential; any regional estimate of woody encroachment that fails to account for removals will certainly lead to an overestimate of the effects of encroachment on aboveground carbon accumulation or any such large-scale responses. Similarly, the low-frequency occurrence of very high encroachment rates must not be overlooked in assessing regional rates of change. It is easy and correct to conclude that small changes in biomass multiplied over large areas can amount to large total carbon flux. What is harder to appreciate is that when site-level change tends, even strongly, toward zero, the balance of positive and negative end members can become as important in dictating net regional flux as the typical site-level behavior that ecological studies typically describe.

\section{Juniper Encroachment and the Regional Carbon Balance}

Before translating changes in aboveground juniper biomass directly into regional changes in terrestrial carbon stocks, one must make two major assumptions. First, it has to be assumed that changes in aboveground composition are not accompanied by any significant changes in belowground biomass. Second, it has to be assumed that the gains in aboveground juniper mass are not substantially compensated for by decreases in the aboveground mass of grasses and shrub mass.

With respect to the first assumption, we know that encroachment of shrubs (i.e., Prosopis and) into semiarid grasslands can result in either increases or decreases in belowground carbon stores (Jackson et al. 2002; Hibbard et al. 2003). Although the rooting depth of western juniper is generally considered to be deeper than that of the sagebrush it is replacing, we have no reliable information suggesting that juniper encroachment in the Great Basin either increases or decreases belowground carbon stores.

With respect to the second assumption, the highest biomass shrubs with which juniper competes in Oregon (namely, Artemisia spp.) have an average biomass per unit crown cover of only $8 \%$ that of juniper (derived from juniper allometry of Sabin [2008], and sage allometry of Rittenhouse and Sneva [1977]). This means that even when juniper cover replaces sage cover on a one-to-one basis (as reported by Miller et al. 2005), aboveground biomass lost in shrubs is less than $8 \%$ that gained in aboveground juniper biomass.

Assuming that the changes in terrestrial carbon stocks associated with juniper encroachment approximate the 
observed changes in the aboveground mass of juniper carbon, we can easily compare the impact of encroachment to the impact of other vegetation dynamics in Oregon. For instance, as illustrated in Figure 8A, we estimate the average accumulation of carbon per unit area in undisturbed juniper woodlands to be $2.9 \mathrm{~kg} \mathrm{C} \cdot \mathrm{m}^{-1} \cdot \mathrm{yr}^{-1}, 20 \%$ of that modeled for Oregon forest types (Turner et al. 2007). When these flux estimates are scaled up across all of Oregon (Fig. 8B) it becomes apparent how net carbon accumulation is really the small difference between much larger gains and losses (harvest and fire in the case of forests, and tree removal in the case of juniper woodlands). Also apparent in Figure 8B is that the carbon accumulation attributed to juniper encroachment in all of Oregon (about $0.2 \mathrm{Tg} \mathrm{C} \cdot \mathrm{yr}^{-1}$ ) is a very small amount compared to net forest growth or even wildfire emissions.

\section{IMPLICATIONS}

The area potentially subject to encroachment by juniper in North America is vast. As such, associated changes in aboveground biomass can have a significant impact on continental carbon stocks, even when the changes per unit area are small relative to other terrestrial carbon fluxes. Most of what we know about juniper encroachment rates comes from localized studies designed to identify the drivers of encroachment and has understandably targeted areas where encroachment is known to be occurring. However, as illustrated in this study, the net change in biomass over an entire region is driven as much by the balance of end-members as it is by central tendencies. In other words, locations exhibiting unusually high rates of encroachment and those where juniper has been removed by wildfire or through some management prescription are as important in defining net change as undisturbed locations exhibiting typical encroachment rates. Change detection over 20 sequential years of Landsat imagery showed promise in identifying patterns of vegetation change throughout juniper woodlands and associated range communities of eastern Oregon. However, correlating this change with a single vegetation process remains challenging. Although it would be imprudent to trivialize the capacity of juniper encroachment to alter the function of shrublands ecosystems, when balanced against removal its contribution to regional carbon balance over the last $20 \mathrm{yr}$ appears to be quite small.

\section{AKNOWLEDGMENTS}

We would like to thank David Azuma, Michael Golden, and Dale Weyermann of the US Forest Service for providing current and historical photo imagery of Oregon's juniper woodlands.

\section{LITERATURE CITED}

ARCHER, S. 1994. Woody plant encroachment into Southwestern grasslands and savannas: rates, patterns, and proximate causes. In: M. Vavra, W. A. Laycock, and R. D. Pieper [EDS.]. Ecological implications of livestock herbivory in the West. Denver, CO, USA: Society for Range Management. p. 13-68.

Archer, S., D. S. Schimel, and E. A. Holland. 1995. Mechanisms of shrubland expansion: land use, climate or $\mathrm{CO}_{2}$ ? Climatic Change 29:91-99.
Archer, S., C. Scifres, C. Bassham, and B. Maggio. 1988. Autogenic succession in a subtropical savanna: conversion of grassland to thorn woodland. Ecological Monographs 58(2):111-127.

Asner, G., S. Archer, R. Hughes, R. Ansley, and C. Wessman. 2003. Net changes in regional woody vegetation cover and carbon storage in Texas drylands, 19371999. Global Change Biology 9:316-335.

Bai, Y., N. Walsworth, B. Roddan, D. A. Hill, K. Broersma, and D. Thompson. 2005. Quantifying tree cover in the forest-grassland ecotone of British Columbia using crown delineation and pattern detection. Forestry Ecology and Management 212:92-100.

Bradley, B., and E. Fleishman. 2008. Relationships between expanding pinyonjuniper cover and topography in the central Great Basin, Nevada. Journal of Biogeography 35:951-964.

Canty, M. J., A. A. Nielsen, and M. Schmidt. 2004. Automatic radiometric normalization of multitemporal satellite imagery. Remote Sensing of Environment 91:441-451.

[CCSP] Climate Change Science Program. 2007. The First State of the Carbon Cycle Report (SOCCR): The North American carbon budget and implications for the global carbon cycle. A Report by the US Climate Change Science Program and the Subcommittee on Global Change Research. Asheville, NC, USA: National Oceanic and Atmospheric Administration, National Climatic Data Center. 242 p.

Chavez, P. S., JR. 1996. Image-based atmospheric corrections-revisited and improved. Photogrammetric Engineering and Remote Sensing 62(9):1025-1036.

Cohen, W. B., T. K. Maiersperger, T. A. Spies, and D. R. Oetter. 2001. Modeling forest cover attributes as continuous variables in a regional context with Thematic Mapper data. International Journal of Remote Sensing 22:2279-2310.

Cohen, W. B., And T. A. SpIEs. 1992. Estimating structural attributes of Douglas-fir/ western hemlock forest stands from LANDSAT and SPOT imagery. Remote Sensing of Environment 41:1-17.

Cohen, W. B., Z. Yang, and R. E. Kennedy. 2010. Detecting trends in forest disturbance and recovery using yearly Landsat time series: 2. TimeSynctools for calibration and validation. Remote Sensing of Environment 114:2911-2924.

Cowlin, R. W., P. A. Briegleb, and F. L. Moravets. 1942. Forest resources of the ponderosa pine region of Washington and Oregon. Washington, DC, USA: USDA Forest Service. Misc. Publ. 490. $99 \mathrm{p}$.

CRIST, E. P. 1985. A TM tasseled cap equivalent transformation for reflectance factor data. Remote Sensing of Environment 17:301-306.

Davies, K. W., S. L. Petersen, D. D. Johnson, D. B. Davis, M. D. Madsen, D. L. Zvirzdin, AND J. D. BATES. 2010. Estimating juniper cover from NAIP imagery and evaluating relationships between potential cover and environmental variables. Rangeland Ecology \& Management 63:630-637.

Gedney, D. R., D. L. Azuma, C. L. Bolsinger, and N. McKay. 1999. Western Juniper in Eastern Oregon. Portland, OR, USA: USDA Forest Service, Pacific Northwest Research Station. General Technical Report PNW-GTR-464. 64 p.

Gedney, D. R., P. M. Bassett, and M. A. Mel. 1989. Timber Resource Statistics for all Forest Land, Except National Forests, in Eastern Oregon. Portland, OR, USA: USDA Forest Service, Pacific Northwest Research Station. Resource Bulletin No. PNW-164. 25 p.

Healey, S. P., W. B. Cohen, T. A. Spies, M. Moeur, D. Pflugmacher, M. G. Whitley, and M. LeFsky. 2008. The relative impact of harvest and fire upon landscape-level dynamics of older forests: lessons from the Northwest Forest Plan. Ecosystems 11:1106-1119.

Hibbard, K. A., D. S. Schimel, S. Archer, D. S. OJima, and W. Parton. 2003. Grassland to woodland transitions: integrating changes in landscape structure and biogeochemistry. Ecological Applications 13(4):911-926.

Hill, D. A., and D. G. Leckie. 1999. Automated interpretation of high spatial resolution digital imagery for forestry. Victoria, BC, Canada: Canadian Government Publishing Center, Pacific Forestry Centre. 395 p.

Houghton, R. A., and C. L. Goodale. 2004. Effects of land-use change on the carbon balance of terrestrial ecosystems. In: R. S. DeFries, G. P. Asner, and R. A. Houghton [EDS.]. Ecosystems and land use change. Washington, DC, USA: American Geophysical Union. p. 85-98.

Houghton, R. A., J. L. Hackler, and K. T. LAWrence. 1999. The US carbon budget: contributions from land-use change. Science 285:574-578. 
Jackson, R. B., J. L. Banner, E. G. Jobbagy, W. T. Pockman, and D. H. Wall. 2002. Ecosystem carbon loss with woody plant invasion of grasslands. Nature 418:623-626.

JoHnson, D. D., AND R. F. MILleR. 2006. Structure and development of expanding western juniper woodlands as influenced by two topographic variables. Forestry Ecology and Management 229:7-15.

Kagen, J., AND S. Calcco. 1992. Manual of Oregon actual vegetation. Portland, OR, USA: Oregon Gap Analysis Program. 162 p.

Kennedy, R. E., Z. Yang, and W. B. Cohen. 2010. Detecting trends in forest disturbance and recovery using yearly Landsat time series: 1 . LandTrendrtemporal segmentation algorithms, Remote Sensing of Environment 114: 2897-2910.

Kennedy, R. E., Y. Zhioiang, W. Cohen, E. Pfaff, J. Braaten, and P. Nelson. (In press). Spatial and temporal patterns of forest disturbance and regrowth within the area of the Northwest Forest Plan. Remote Sensing of Environment.

Knapp, A. K., J. M. Briggs, S. L. Collins, S. R. Archer, M. S. Bret-Harte, B. E. Ewers, D. P. Peters, D. R. Young, G. R. Shaver, E. Pendall, and M. B. Cleary. 2008. Shrub encroachment in North American grasslands: shifts in growth form dominance rapidly alters control of ecosystem carbon inputs. Global Change Biology 14:615-623.

KnapP, P. A., AND P. T. Soule. 1998. Recent Juniperus occidentalis (western juniper) expansion on a protected site in central Oregon. Global Change Biology 4:347-357.

Miller, R. F., J. D. Bates, T. J. Svejcar, F. B. Pierson, and L. E. Eddleman. 2005. Biology, ecology and management of western juniper (Juniperus occidentalis). Burns, OR, USA: Oregon State University. Agricultural Experimental Station Technical Bulletin No. 152. 80 p.

MILleR, R. F., AND J. R. Rose. 1995. Historic expansion of Juniperus occidentalis (western juniper) in southeast Oregon. Great Basin Naturalist 55(1):37-45.

Miller, R. F., AND J. A. Rose. 1999. Fire history and western juniper encroachment in sagebrush steppe. Journal of Range Management 52:550-559.

Miller, R. F., and R. J. Tausch. 2002. The role of fire in juniper and pinyon woodlands: a descriptive analysis. Proceedings: The First National Congress on Fire, Ecology, Prevention, and Management; 27 November-1 December 2000; San Diego, CA, USA. Tallahassee, FL, USA: Tall Timbers Research Station. p. 15-30.

OMERNIK, J. M. 1987. Ecoregions of the conterminous United States. Map (scale 1:7,500,000). Annals of the Association of American Geographers 77:118-125.

Pacala, S. W., G. C. Hurtt, D. Baker, P. Peylin, R. A. Houghton, R. A. Birdsey, L. Heath, E. T. Sundquist, R. F. Stallard, P. Ciais, P. Moocroft, J. P. Caspersen,
E. Shevliakova, B. Moore III, G. Kohlmaier, E. Holland, M. Gloor, M. E. Harmon, S. M. Fan, J. L. Sarmiento, C. L. Goodale, D. Schimel, and C. B. Field. 2001. Consistent land- and atmosphere-based US carbon sink estimates. Science 285:574-578.

Rittenhouse, L. R., and F. A. Sneva. 1977. A technique for estimating big sagebrush production. Journal of Range Management 30:68-70.

SABIN, B. S. 2008. Relationship between allometric variables and biomass in western juniper (Juniperus occidentalis) [thesis]. Corvallis, OR, USA: Oregon State University. $129 \mathrm{p}$.

Sankey, T. T., and M. J. Germino. 2008. Assessment of juniper encroachment with the use of satellite imagery and geospatial data. Rangeland Ecology \& Management 61:412-418.

Savage, M., and T. W. Swetnam. 1990. Early 19th-century fire decline following sheep pasturing in a Navajo ponderosa pine forest. Ecology 71(6):2374-2378.

Scholes, R. J., AND S. R. Archer. 1997. Tree-grass interactions in savannas. Annual Review of Ecology and Systematics 28:517-544.

Song, C., T. Schroeder, and W. B. Cohen. 2007. Predicting temperate conifer forest successional stage distributions with multitemporal Landsat Thematic Mapper imagery. Remote Sensing of Environment 106:228-237.

Soule, P. T., P. A. Knapp, and H. D. Grissino-Mayer. 2004. Human agency, environmental drivers, and western juniper establishment during the late Holocene. Ecological Applications 14(1):96-112.

Strand, E., L. Vierling, A. Smith, and S. Bunting. 2008. Net changes in aboveground woody carbon stock in western juniper woodlands, 1946-1998. Journal of Geophysical Research 113:G01013. doi:10.1029/2007JG000544

Swetnam, T. W., C. BaIsAn, And M. K. KaIB. 2010. Forest fire histories of La Frontera: fire-scar reconstructions of fire regimes in the United States/Mexico borderlands. In: G. L. Webster and C. J. Bahre [EDS.]. Vegetation and flora of La Frontera: historic vegetation change along the United States/Mexico Boundary. Albuquerque, NM, USA: University of New Mexico Press. p. 95-119.

Turner, D., D. Ritts, B. E. Law, W. B. Cohen, Z. Yang, T. Hudiburg, J. L. Campbell, and M. Duane. 2007. Scaling net ecosystem production and net biome production over a heterogeneous region in the western United States. Biogeosciences 4(4):597-612.

VAN AukEN, W. 0. 2000. Shrub invasions of North American semi-arid grasslands. Annual Review of Ecology and Systematics 31:197-216.

Weisberg, P. J., E. Lingua, and R. B. Pillal. 2007. Spatial patterns of pinyon-juniper woodland expansion in central Nevada. Rangeland Ecology \& Management 60:115-124. 